\title{
Effect of phosphorus limitation on elemental composition and stable carbon isotope fractionation in a marine diatom growing under different $\mathrm{CO}_{2}$ concentrations
}

\author{
Frank Gervais ${ }^{1}$ and Ulf Riebesell \\ Alfred Wegener Institute for Polar and Marine Research, P.O. Box 1201 61, D-27515 Bremerhaven, Germany
}

\begin{abstract}
Blooms of the marine diatom Skeletonema costatum were initiated in closed-system batch cultures with P-deficient

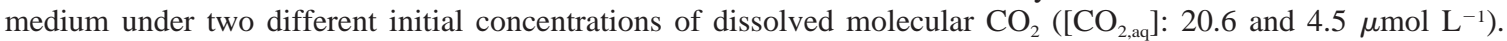
Algal C:N:P ratios strongly increased with decreasing $\mathrm{P}$ concentration. In the exponential growth phase, $\mathrm{C}: \mathrm{N}$ ratios were $1.3 \mathrm{~mol} \mathrm{~mol}{ }^{-1}$ higher in the low relative to the high $\left[\mathrm{CO}_{2, \text { aq }}\right]$ treatment. There was no $\left[\mathrm{CO}_{2, \text { aq }}\right]$ effect on $\mathrm{C}: \mathrm{N}: \mathrm{P}$ ratios during P-limited growth. Carbon isotope fractionation $\left(\varepsilon_{p}\right)$ was $2-3 \%$ higher in the high $\left[\mathrm{CO}_{2, \mathrm{aq}}\right]$ treatment. With growth rate decreasing due to $\mathrm{P}$ limitation, $\varepsilon_{p}$ increased in both $\left[\mathrm{CO}_{2, \mathrm{aq}}\right]$ treatments by $2-3 \%$ despite decreasing $\left[\mathrm{CO}_{2, \mathrm{aq}}\right]$. Under these conditions the effect of decreasing growth rate on isotope fractionation strongly dominated over that of declining $\mathrm{CO}_{2}$ availability. When extrapolated to the natural environment, these results imply that systematic changes in algal growth, as occurring during the course of phytoplankton blooms, may affect algal isotope fractionation. These results severely complicate the interpretation of carbon isotope measurements in suspended and sedimentary organic matter.
\end{abstract}

Variations in atmospheric $\mathrm{CO}_{2}$ concentration lead to significant changes in surface ocean carbonate chemistry (WolfGladrow et al. 1999). Laboratory experiments examining possible responses of marine phytoplankton to these changes typically have been performed under steady state conditions (e.g., Johnston and Kennedy 1998). This ensured that the responses obtained could be assigned to the single factor varied in the experimental setup. Often, the nutrient concentrations in these experiments were constant and/or much higher than observed under natural conditions. In the ocean and especially during phytoplankton blooms, however, several environmental factors and algal physiological characteristics change simultaneously, and eventually nutrients become growth limiting. Such conditions may lead to phytoplankton responses that differ from those obtained under steady state. To test this, we studied the changes of two algal characteristics in the course of simulated blooms of a marine diatom: (1) $\mathrm{C}: \mathrm{N}: \mathrm{P}$ ratio and (2) composition of stable carbon isotopes.

The $\mathrm{C}: \mathrm{N}: \mathrm{P}$ ratio in marine phytoplankton species growing under nutrient-replete conditions is clearly dependent on $\left[\mathrm{CO}_{2, \mathrm{aq}}\right]$ (Burkhardt and Riebesell 1997; Burkhardt et al. $1999 \mathrm{~b})$. With declining nutrient supply, distinct changes in the cellular content of protein, lipids, free amino acids, and carbohydrates of microalgae are observed (Rhee 1978; Vårum and Myklestad 1984; Berdalet et al. 1994). As a consequence, their elemental ratios show increasing deviations from the Redfield ratio $(\mathrm{C}: \mathrm{N}: \mathrm{P}=106: 16: 1)$ with increas-

\footnotetext{
${ }^{1}$ Corresponding author (fgervais@awi-bremerhaven.de).
}

\section{Acknowledgements}

We acknowledge the support of Anja Terbrüggen and Anke Dauelsberg, who performed $\mathrm{C} / \mathrm{N}, \delta^{13} \mathrm{C}_{\mathrm{POC}}$, and DIC measurements. $\delta^{13} \mathrm{C}_{\mathrm{DIC}}$ was analyzed in the laboratory of Howard Spero (University of California, Davis). Steffen Burkhardt and two reviewers are thanked for their critical comments on the manuscript. Our research was supported by the German-Israeli Cooperation in Marine Sciences (Mars 2/3), which is funded by the German Federal Ministry of Education and Research (BMBF). ing nutrient shortage (Sakshaug and Holm-Hansen 1977). These deviations are much larger than $\left[\mathrm{CO}_{2, \mathrm{aq}}\right]$-mediated $\mathrm{C}$ : $\mathrm{N}$ : P changes (cf. Burkhardt and Riebesell 1997; Burkhardt et al. 1999b). Until now it is not clear whether $\mathrm{CO}_{2}$-related effects on algal $\mathrm{C}: \mathrm{N}: \mathrm{P}$ ratios are occurring and of any quantitative significance in algae growing under nutrient-limiting conditions.

Primary factors determining the fractionation of stable carbon isotopes $\left(\varepsilon_{p}\right)$ in microalgae are $\left[\mathrm{CO}_{2, \mathrm{aq}}\right]$, growth rate, cells size, and cell shape (Rau et al. 1996; Laws et al. 1997; Popp et al. 1998; Burkhardt et al. 1999a). In addition, $\varepsilon_{p}$ may also be strongly influenced by the factor limiting phytoplankton growth rate (e.g., nutrients vs. light; Riebesell et al. 2000). All these results were achieved by steady state laboratory experiments in chemostats or dilute batch cultures with low algal biomass. Based on this approach, it is difficult to predict changes in $\varepsilon_{p}$ under natural conditions prevailing during phytoplankton blooms. During blooms, $\left[\mathrm{CO}_{2, \mathrm{aq}}\right] \mathrm{de}-$ creases due to algal carbon uptake, and algal growth rate eventually decreases due to nutrient limitation. These two processes have been shown to affect $\varepsilon_{p}$ in opposite ways (Laws et al. 1997). It is not clear, however, to what extent the $\delta^{13} \mathrm{C}_{\mathrm{POC}}$ signal produced during the course of a phytoplankton bloom is influenced by each of these processes.

To address these questions, we cultivated the marine diatom Skeletonema costatum (Grev.) Cleve in dilute closedsystem batch cultures with low initial phosphate concentration under low and high $\left[\mathrm{CO}_{2, \mathrm{aq}}\right]$, respectively. We followed the algal cellular $\mathrm{C}, \mathrm{N}$, and $\mathrm{P}$ content and the isotopic composition of algal organic carbon during two controlled $S$. costatum blooms until algal growth ceased. The associated changes in phosphate concentration, in the carbonate system, and in the isotopic composition of $\mathrm{CO}_{2, \mathrm{aq}}$ in the growth medium were measured. We calculated stable carbon isotope fractionation associated with every cell division cycle of $S$. costatum during the exponential growth and the limitation phase. The present study is the first to investigate the influence of phosphate limitation on the carbon isotope fractionation by a marine microalga. 


\section{Material and methods}

Cultures and general culture conditions-We studied a strain of the marine diatom Skeletonema costatum (Grev.) Cleve originally isolated from the North Sea in 1997. During the experiments, the algae (mean cell diameter, $8 \mu \mathrm{m}$; mean cell volume, $400 \mu \mathrm{m}^{3}$ ) were maintained in dilute batch cultures in 2.4-liter borosilicate bottles (air-sealed with PBTlined screw caps) at $15^{\circ} \mathrm{C}$ (light-thermostat Rumed 1200). The bottles were closed without headspace and were rotated several times daily to keep the algal chains in suspension. The algae grew in $0.2-\mu \mathrm{m}$ filtered natural North Sea water (salinity 29.4) that was enriched with nutrients and vitamins according to the f/2 medium (Guillard and Ryther 1962) except that nitrate and silicate were added in concentrations of 100 and $106 \mu \mathrm{mol} \mathrm{L}{ }^{-1}$. The phosphate concentration varied in the course of the experiments (see below). The cultures were grown under continuous light (fluorescent tubes: Osram Lumilux deluxe daylight L36/12-950) with a photon flux density of $150 \mu \mathrm{mol}$ photons $\mathrm{m}^{-2} \mathrm{~s}^{-1}$ (measured inside the incubation bottles with a QSL-100 quantum scalar irradiance meter, Biospherical Instruments). This photon flux density is subsaturating since the light saturation index $\left(I_{k}\right)$ of $S$. costatum is $203 \mu \mathrm{mol}$ photons $\mathrm{m}^{-2} \mathrm{~s}^{-1}$ under continuous light (Gilstad et al. 1993). Bacterial biovolume (determined in samples stained with acridine orange with the help of epifluorescence microscopy) never exceeded $3 \%$ of algal biovolume.

Growth experiments and sampling-We conducted two consecutive experiments with different starting concentrations of dissolved molecular carbon dioxide $\left[\mathrm{CO}_{2, \mathrm{aq}}\right]$ in the culture medium (20.6 and $4.5 \mu \mathrm{mol} \mathrm{L}{ }^{-1}$, respectively). These concentrations were achieved by adjustment of $\mathrm{pH}$ to values of 8.0 and 8.6, respectively, through the addition of $1 \mathrm{~N} \mathrm{HCl}$ or $1 \mathrm{~N} \mathrm{NaOH}$ (see Burkhardt and Riebesell 1997 for further details). Algae were preadapted to the experimental $\left[\mathrm{CO}_{2, \mathrm{aq}}\right]$ under phosphate-replete conditions $\left(6.25 \mu \mathrm{mol} \mathrm{P} \mathrm{L}^{-1}\right)$ for at least nine cell divisions. Afterward, the exponentially growing algae were inoculated at low cell concentration (20-40 cells $\mathrm{ml}^{-1}$ ) into 29 bottles containing 2.4 liters of medium with low phosphate concentration $\left(0.14 \mu \mathrm{mol} \mathrm{P} \mathrm{L}^{-1}\right)$ and the corresponding $\left[\mathrm{CO}_{2, \mathrm{q} q}\right]$. Algal growth was monitored in two of these bottles by cell counting (see below). After $3 \mathrm{~d}$ (i.e., six cell divisions), we started our sampling protocol. For the first sampling, we had to pool the contents of three bottles (in duplicate), as the algal biomass was still low so that large filtration volumes were necessary. With increasing algal biomass, sampling continued with the analysis of three single replicate bottles every $12 \mathrm{~h}$ (i.e., following every cell division) until the end of the seventh day. In each bottle (and in the mixtures of the first sampling) we measured $\mathrm{pH}$ (microprocessor pH-Meter WTW pH 3000, calibrated with NBS buffer solutions) and took subsamples to determine algal and bacterial cell concentration, soluble reactive phosphorus (SRP), total alkalinity (TA), dissolved inorganic carbon (DIC), and the isotopic composition of DIC $\left(\delta^{13} \mathrm{C}_{\mathrm{DIC}}\right)$. Furthermore, we filtered the cell suspension on precombusted $\left(12 \mathrm{~h}, 500^{\circ} \mathrm{C}\right) \mathrm{GF} / \mathrm{C}$ glass fiber filters for the analysis of particulate organic carbon and nitrogen $(\mathrm{POC}, \mathrm{PON})$, the isotopic composition of POC $\left(\delta^{13} \mathrm{C}_{\mathrm{POC}}\right)$, and particulate phosphorus (PP).

Determination of cell concentration, cell volume, SRP, and $P P$-Two subsamples per bottle were preserved with Lugol's iodine and settled in counting chambers. Cells were counted under an inverted microscope. Cell dimensions of 60 cells were measured in a sample from one bottle at each sampling time. SRP in the GF/C filtrate was analyzed in a spectrophotometer (100 $\mathrm{mm}$ cuvette) in triplicate according to the ammonium-molybdate method (Strickland and Parsons 1972). For PP analysis, the GF/C filters (stored at $-20^{\circ} \mathrm{C}$, three filters per bottle) were digested in $1 \%$ potassium persulphate solution in an autoclave at $121^{\circ} \mathrm{C}$ for $1 \mathrm{~h}$. Subsequent analysis also followed the ammonium-molybdate method (10 $\mathrm{mm}$ cuvette).

Analysis of alkalinity and dissolved organic carbon-Subsamples for the analysis of TA and DIC were preserved with $0.12 \mathrm{mg} \mathrm{HgCl} \mathrm{L}^{-1}$, stored at $4^{\circ} \mathrm{C}$, and analyzed in duplicate. TA was calculated from linear Gran plots (Gran 1952) after potentiometric titration of $100 \mathrm{ml}$ sample with $0.05 \mathrm{~N} \mathrm{HCl}$ (Brewer et al. 1986). DIC was measured by coulometric titration (UIC coulometer) in an automated gas extraction system (Johnson et al. 1993). $\left[\mathrm{CO}_{2, a q}\right]$ and $\mathrm{pH}$ were calculated from DIC concentration, TA, temperature, salinity, and concentrations of silicate and phosphate based on the dissociation constants of Goyet and Poisson (1989). Calculated and measured $\mathrm{pH}$ differed by less than 0.05 units.

Analysis of POC, PON, and isotopic composition of POC and $\mathrm{DIC}-\mathrm{GF} / \mathrm{C}$ filters (stored at $-20^{\circ} \mathrm{C}, 3-4$ filters per bottle) were acidified with $0.1 \mathrm{~N} \mathrm{HCl}$ to remove inorganic carbon. The subsequent analyses of $\mathrm{C} / \mathrm{N}$ content and the isotopic composition of POC $\left(\delta^{13} \mathrm{C}_{\mathrm{POC}}\right)$ were performed on a mass spectrometer (ANCA-SL 20-20, Europa Scientific). The carbon isotopic composition of the dissolved inorganic carbon $\left(\delta^{13} \mathrm{C}_{\mathrm{DIC}}\right)$ was determined by acidifying $5 \mathrm{ml}$ of unfiltered subsamples (preserved with $0.12 \mathrm{mg} \mathrm{HgCl}_{2} \mathrm{~L}^{-1}$, stored at $4^{\circ} \mathrm{C}$ ) in vacuum with $0.5 \mathrm{ml}$ of purified ortho-phosphoric acid. The released $\mathrm{CO}_{2}$ was stripped, collected, and analyzed on a Micromass Optima isotope ratio mass spectrometer. The isotopic composition of $\mathrm{CO}_{2, \text { aq }}\left(\delta^{13} \mathrm{C}_{\mathrm{CO}_{2}}\right)$ was calculated from $\delta^{13} \mathrm{C}_{\text {DIC }}$ by taking into consideration the $\mathrm{pH}$ and temperature dependence of carbon isotope partitioning according to Zeebe and Wolf-Gladrow (in prep.) and Mook et al. (1974) using the dissociation constants of Goyet and Poisson (1989). Carbon isotopic compositions are reported in $\delta$ notation relative to the PDB standard.

Calculation of carbon isotope fractionation-The stable carbon isotope fractionation associated with photosynthetic $\mathrm{CO}_{2}$ fixation $\left(\varepsilon_{p}\right)$ was calculated relative to $\delta^{13} \mathrm{C}_{\mathrm{CO}_{2}}$ according to the equation of Freeman and Hayes (1992):

$$
\varepsilon_{p}=\left(\delta^{13} \mathrm{C}_{\mathrm{CO}_{2}}-\delta^{13} \mathrm{C}_{\mathrm{POC}}\right) /\left(1+\delta^{13} \mathrm{C}_{\mathrm{POC}} / 1000\right) .
$$

In the standard procedure, this calculation is based on the values of $\delta^{13} \mathrm{C}_{\mathrm{CO}_{2}}$ and $\delta^{13} \mathrm{C}_{\mathrm{POC}}$ at the time of sampling. This approach is useful as long as $\delta^{13} \mathrm{C}_{\mathrm{CO}_{2}}$ and $\varepsilon_{p}$ do not change (Fry 1996). This can be true in the course of a well-con- 
trolled laboratory experiment (continuous culture or dilute batch culture). During a phytoplankton bloom, however, $\delta^{13} \mathrm{C}_{\mathrm{CO}_{2}}$ increases due to algal carbon isotope fractionation during $\mathrm{CO}_{2}$ consumption. Moreover, increasing nutrient shortage in the course of the bloom leads to a reduction of algal growth rate and a subsequent increase in carbon isotope fractionation. Therefore, the algal $\delta^{13} \mathrm{C}_{\mathrm{POC}}$ signal will change with every cell division cycle under growth-limiting conditions. In this case, a calculation of $\varepsilon_{p}$ on the basis of the measured values results in inaccurate estimates because the measured $\delta^{13} \mathrm{C}_{\mathrm{POC}}$ consists of a mixture of different signals accumulated under changing conditions. To overcome this problem, we calculated the isotopic composition of the new algal POC built up between two consecutive samplings (i.e., between two cell divisions) according to

$$
\begin{aligned}
& \delta^{13} \mathrm{C}_{\mathrm{POC} t=n \rightarrow n+1} \\
& =\left([\mathrm{POC}]_{t=n+1} \cdot \delta^{13} \mathrm{C}_{\mathrm{POC} t=n+1}-[\mathrm{POC}]_{t=n} \cdot \delta^{13} \mathrm{C}_{\mathrm{POC} t=n}\right) \\
& \quad \div\left([\mathrm{POC}]_{t=n+1}-[\mathrm{POC}]_{t=n}\right)
\end{aligned}
$$

where $[\mathrm{POC}]_{t=n}$ and $[\mathrm{POC}]_{t=n+1}$ are the mean POC concentrations and $\delta^{13} \mathrm{C}_{\mathrm{POC} t=n}$ and $\delta^{13} \mathrm{C}_{\mathrm{POC} t=n+1}$ are the mean isotopic compositions of POC at times $t=n$ and $t=n+1$, respectively (cf. Erez et al. 1998). We then estimated the momentary carbon isotope fractionation $\left(\varepsilon_{p, \text { mom }}\right)$ associated with each cellular division cycle by using Eq. 1 with $\delta^{13} \mathrm{C}_{\mathrm{POC} t=n \rightarrow n+1}$ (Eq. 2) and the mean of $\delta^{13} \mathrm{C}_{\mathrm{CO}_{2}}$ between two samplings. For comparison we also calculated the accumulated carbon isotope fractionation $\left(\varepsilon_{p \text {,acc }}\right)$ by directly inserting the measured values of $\delta^{13} \mathrm{C}_{\mathrm{POC}}$ and $\delta^{13} \mathrm{C}_{\mathrm{CO}_{2}}$ in Eq. 1 .

\section{Results}

Growth-In both experiments, cell concentration of $S$. costatum increased exponentially until the end of the fifth day; afterward the increase slowed down considerably (Fig. 1). Owing to differences in the inoculum size, algal biomass was higher in the experiment with low $\left[\mathrm{CO}_{2, \mathrm{aq}}\right]$ (Fig. 1). At the end of the experiments, cell concentration of both $\left[\mathrm{CO}_{2, \mathrm{aq}}\right]$ treatments converged, whereas POC concentration remained higher in the low $\left[\mathrm{CO}_{2, \mathrm{aq}}\right]$ treatment (Fig. 1) due to higher $\mathrm{C}$ quotas (see below). The maximum specific growth rate $\left(\mu_{\max }\right)$ during the exponential growth phase calculated on the basis of cell concentration (Fig. 1A) and POC concentration (Fig. 1B) was $1.40 \mathrm{~d}^{-1}$ (low $\left[\mathrm{CO}_{2, \mathrm{aq}}\right]$ ) and 1.50 $\mathrm{d}^{-1}$ (high $\left[\mathrm{CO}_{2, \mathrm{aq}}\right]$ ) (Fig. 1). The mean cell volume was not significantly different comparing both experiments and showed no significant decrease or increase throughout the experiments (low $\left[\mathrm{CO}_{2, \mathrm{aq}}\right], 405 \pm 43 \mu \mathrm{m}^{3}$; high $\left[\mathrm{CO}_{2, \mathrm{aq}}\right], 390$ $\left.\pm 41 \mu \mathrm{m}^{3}\right)$.

The termination of the exponential growth phase was obviously due to $\mathrm{P}$ deficiency since SRP was almost completely incorporated into algal PP after $5 \mathrm{~d}$ (i.e., 9-10 cell divisions) in both experiments (Fig. 2A). In the limitation phase (days 6-7), PP remained constant (Fig. 2A), whereas cell concentration and POC still increased by a factor of 2 to 3 (Fig. 1).

During the experiments, mean total alkalinity remained constant (low $\left[\mathrm{CO}_{2, \mathrm{aq}}\right], 2.55 \mathrm{mmol} \mathrm{L}{ }^{-1}$; high $\left[\mathrm{CO}_{2, \mathrm{aq}}\right], 2.14$

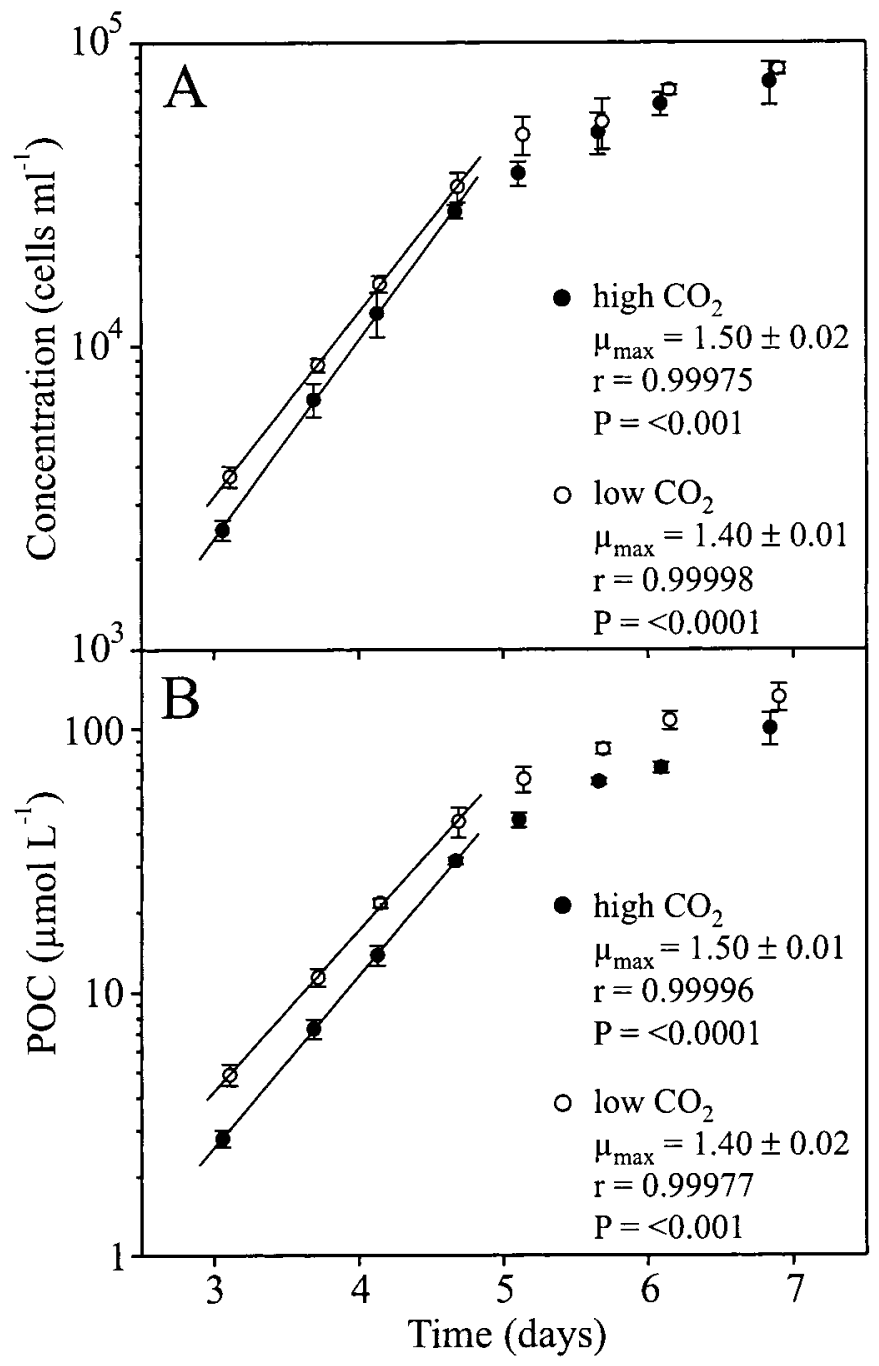

Fig. 1. S. costatum. (A) Cell concentration and (B) concentration of algal particulate organic carbon (POC) during the experimental period. The regression line and the given parameters ( \pm standard error) result from linear regression analysis of natural log transformed data of days 4 and 5. Error bars represent the standard deviation of the mean results of the replicate bottles.

mmol L ${ }^{-1}$ ), whereas mean DIC concentration decreased (low $\left[\mathrm{CO}_{2, \mathrm{aq}}\right], 2.01$ to $1.79 \mathrm{mmol} \mathrm{L}{ }^{-1}$; high $\left[\mathrm{CO}_{2, \mathrm{aq}}\right], 2.01$ to 1.87 mmol L ${ }^{-1}$ ), mean $\mathrm{pH}$ increased (Fig. $2 \mathrm{~B}$ ), and mean $\left[\mathrm{CO}_{2, \mathrm{aq}}\right]$ decreased (Fig. 2C).

Cell quotas and nutrient ratios-Mean cellular carbon quotas of $S$. costatum were variable (low $\left[\mathrm{CO}_{2, \text { aq }}\right], 36.8-50.5$

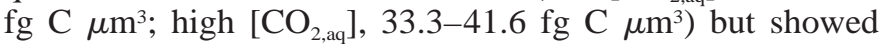
no significant trend during the experiments. The cellular nitrogen quota decreased by about $50 \%$ with increasing algal biomass (Fig. 3A). The cellular phosphorus quota decreased by about $80 \%$ during the exponential growth phase and reached a minimum value in the limitation phase (Fig. 3B).

As a result, the molar $\mathrm{C}: \mathrm{N}, \mathrm{N}: \mathrm{P}$, and $\mathrm{C}: \mathrm{P}$ ratios of $S$. costatum steadily increased with increasing biomass during both experiments (Fig. 4). C: $\mathrm{N}$ ratios ranged from 6 to 18 (Fig. 4A). At low algal biomass $\left(<10 \mu \mathrm{mol}\right.$ POC L $\left.{ }^{-1}\right), \mathrm{C}$ : 


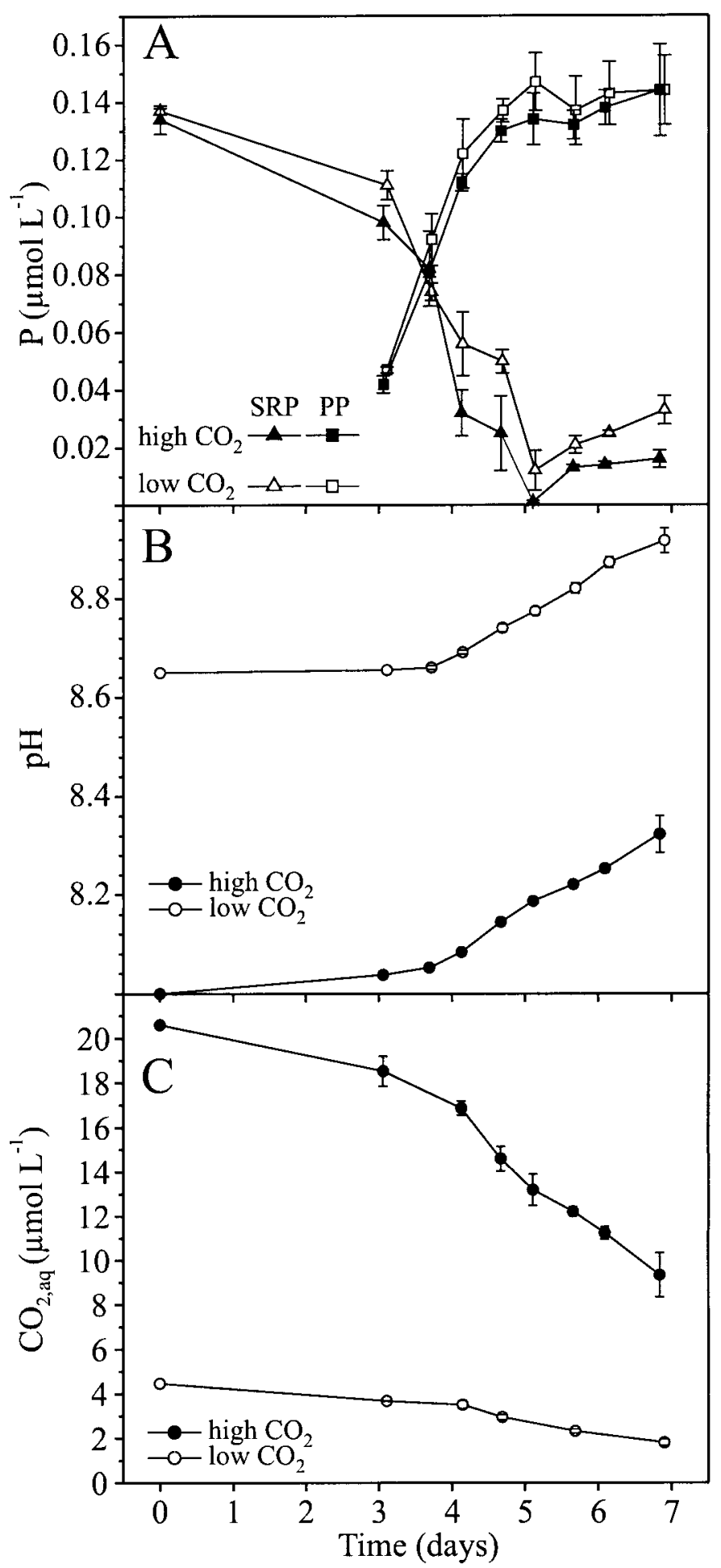

Fig. 2. (A) Concentration of soluble reactive phosphorus (SRP) and algal particulate phosphorus (PP), (B) $\mathrm{pH}$, and (C) $\left[\mathrm{CO}_{2, \text { aq }}\right]$ during the experimental period. Error bars as in Fig. 1.

$\mathrm{N}$ ratios were constant (low $\left[\mathrm{CO}_{2, \mathrm{aq}}\right]$ ) or decreased slightly (high $\left[\mathrm{CO}_{2, \mathrm{aq}}\right]$ ) (Fig. 4A). Between 10 and $65 \mu \mathrm{mol}$ POC L $\mathrm{L}^{-1}$ (i.e., in the exponential growth phase and early limitation phase) $\mathrm{C}: \mathrm{N}$ ratios increased linearly with identical slopes

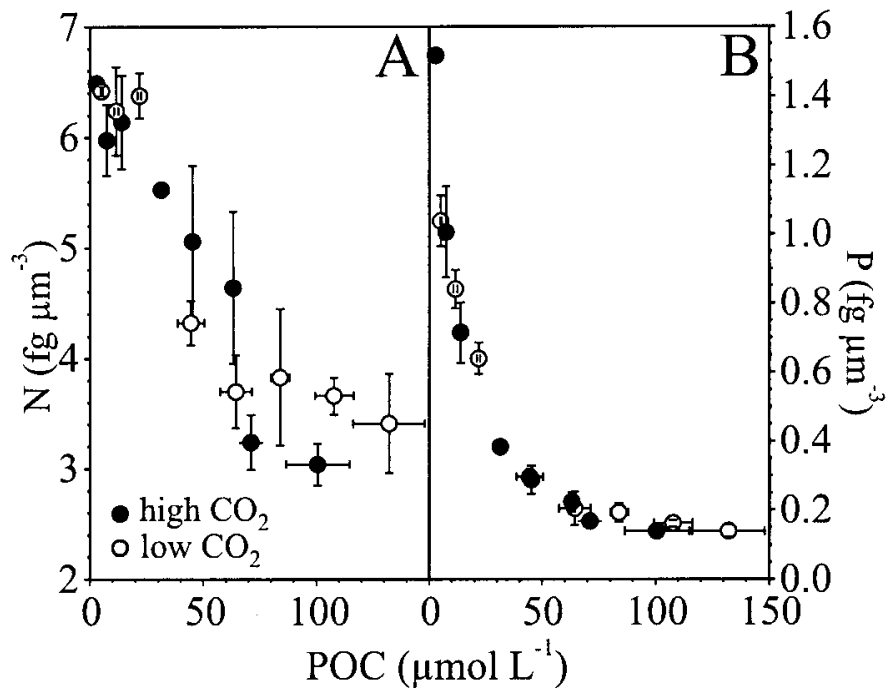

Fig. 3. S. costatum. Cell quotas (relative to cell volume) of (A) nitrogen and (B) phosphorus versus algal POC concentration. Error bars as in Fig. 1.

(Fig. 4A). Below $65 \mu \mathrm{mol} P O C \mathrm{~L}^{-1}$, the $\mathrm{C}: \mathrm{N}$ ratio in the low $\left[\mathrm{CO}_{2, a q}\right]$ experiment was consistently $1.3 \mathrm{~mol} \mathrm{~mol}^{-1}$ higher than in the high $\left[\mathrm{CO}_{2, a q}\right]$ experiment (Fig. 4A). Above

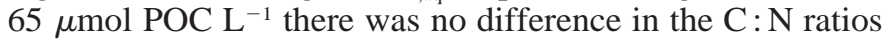
of both $\left[\mathrm{CO}_{2, \mathrm{aq}}\right]$ treatments (Fig. $4 \mathrm{~A}$ ). $\mathrm{N}: \mathrm{P}$ ratios increased from 10 to 56 and were largely the same in both $\left[\mathrm{CO}_{2, \mathrm{aq}}\right]$ treatments over the entire range of algal biomass (Fig. 4B). $\mathrm{C}: \mathrm{P}$ ratios linearly increased in both $\left[\mathrm{CO}_{2, \mathrm{aq}}\right]$ treatments from values of 70 to 1,000 with similar regression parameters (Fig. 4C).

Carbon isotopic composition and carbon isotope fractionation-The isotopic composition of $\mathrm{CO}_{2, \mathrm{aq}}\left(\delta^{13} \mathrm{C}_{\mathrm{CO}_{2}}\right)$ increased almost linearly with increasing algal biomass (Fig. $5 \mathrm{~A})$. The $\delta^{13} \mathrm{C}_{\mathrm{CO}_{2}}$ of the batches of seawater used in both

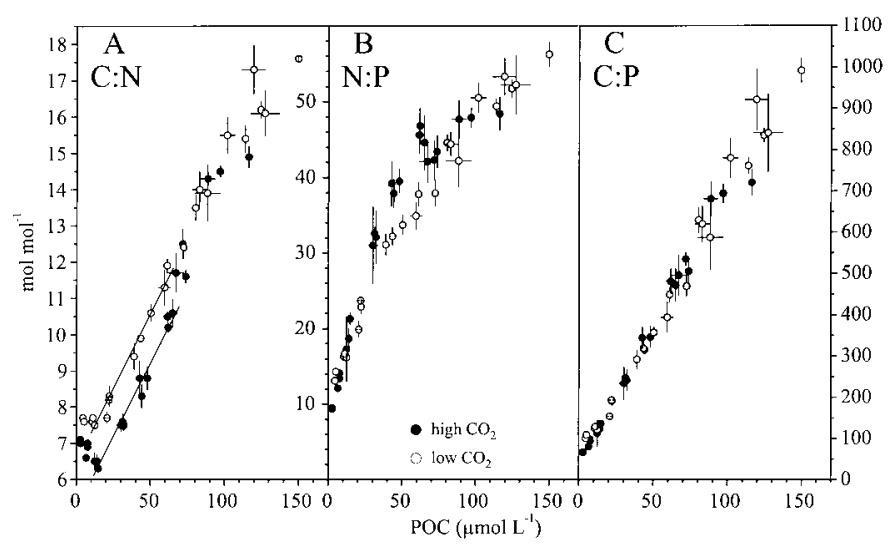

Fig. 4. S. costatum. (A) $\mathrm{C}: \mathrm{N}$, (B) $\mathrm{N}: \mathrm{P}$, and (C) $\mathrm{C}: \mathrm{P}$ ratio versus algal POC in the experiments with low and high $\left[\mathrm{CO}_{2, a q}\right]$. Mean and standard deviation of the parallel analyses in each bottle are shown. The linear regression lines in (A) span the range between 10 and $65 \mu \mathrm{mol} \mathrm{POC} \mathrm{L}{ }^{-1}$. Low $\left[\mathrm{CO}_{2, \text { aq }}\right]$ : intercept $=6.46 \pm 0.16$, slope $=0.082 \pm 0.005, r=0.987$. High $\left[\mathrm{CO}_{2, \mathrm{aq}}\right]$ : intercept $=5.16$ \pm 0.18 , slope $=0.081 \pm 0.004, r=0.9869$. 


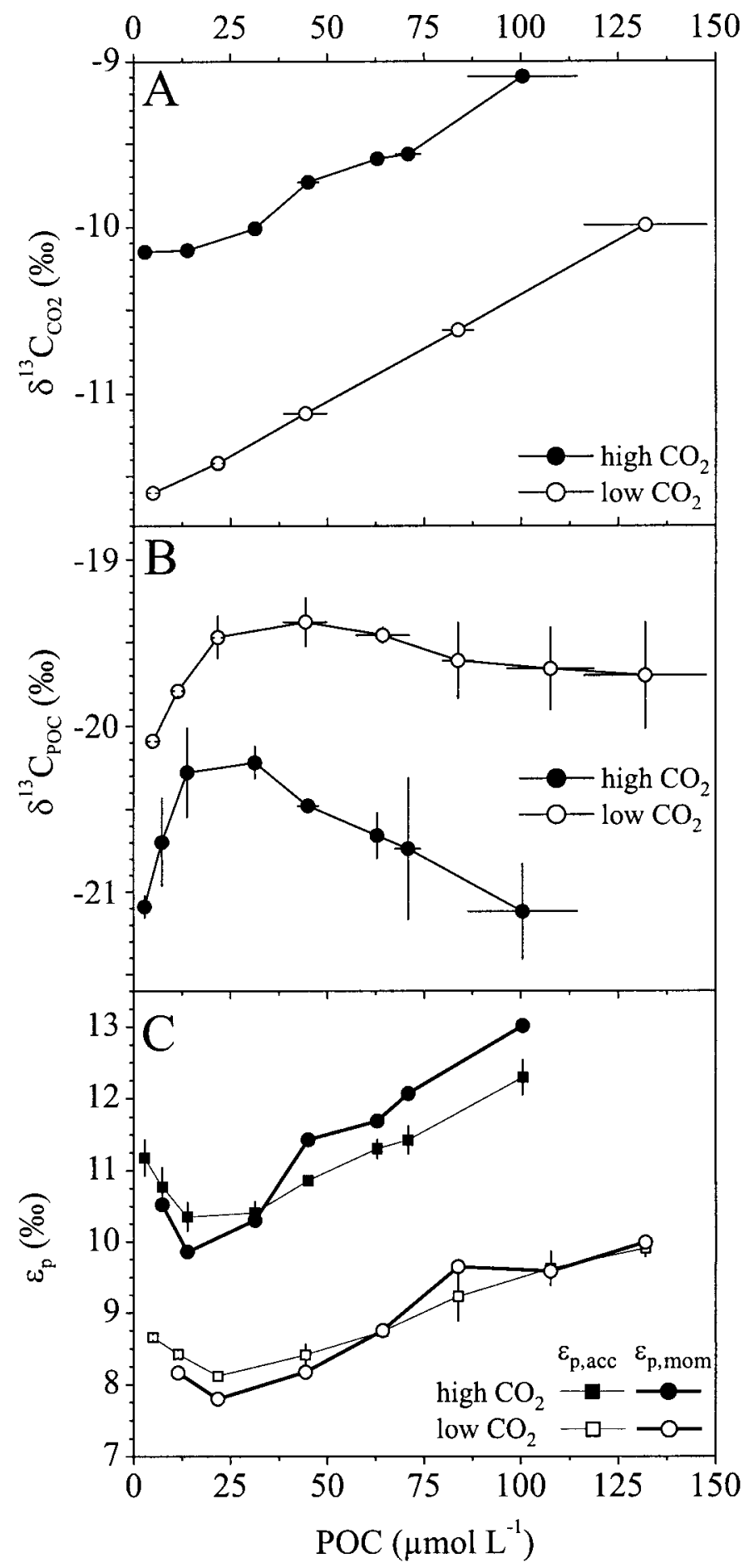

Fig. 5. S. costatum. (A) Isotopic composition of $\mathrm{CO}_{2, \text { aq }}$ $\left(\delta^{13} \mathrm{C}_{\mathrm{CO}_{2}}\right),(\mathrm{B})$ isotopic composition of algal particulate organic carbon $\left(\delta^{13} \mathrm{C}_{\mathrm{POC}}\right)$, and $(\mathrm{C})$ momentary and accumulated carbon isotope fractionation $\left(\varepsilon_{p, \text { mom }}\right.$ and $\left.\varepsilon_{p, \text { acc }}\right)$ versus algal POC in the experiments with low and high $\left[\mathrm{CO}_{2, \mathrm{aq}}\right]$. Error bars as in Fig. 1.

experiments differed by about $1.2 \%$ (Fig. 5A). The isotopic composition of particulate organic carbon $\left(\delta^{13} \mathrm{C}_{\mathrm{POC}}\right)$ was about $1-1.5 \%$ o higher in the low $\left[\mathrm{CO}_{2, \text { aq }}\right]$ treatment (Fig. 5B). Below $25 \mu \mathrm{mol}$ POC $\mathrm{L}^{-1}$ (i.e., in the exponential growth

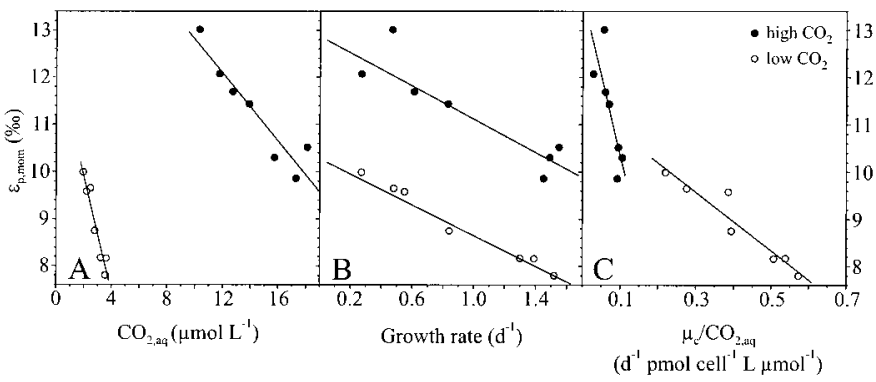

Fig. 6. S. costatum. Momentary carbon isotope fractionation $\left(\varepsilon_{p, \text { mom }}\right)$ versus (A) $\left[\mathrm{CO}_{2, \text { aq }}\right]$, (B) growth rate $(\mu)$, and $(\mathrm{C})$ the ratio $\mu_{c} /\left[\mathrm{CO}_{2, \mathrm{aq}}\right]$ in the experiments with low and high $\left[\mathrm{CO}_{2, \mathrm{aq}}\right] \cdot \mu_{c}=\mu$ - (C cell quota). In (B) and (C), $\mu$ was calculated on the basis of the algal POC concentration of two consecutive samplings. $\left[\mathrm{CO}_{2, \mathrm{aq}}\right]$ in (A) and $(\mathrm{C})$ and $\mathrm{C}$ cell quota in $(\mathrm{C})$ are mean values of two consecutive samplings. Linear regression lines are given in (A), (B), and $(\mathrm{C})$.

phase), $\delta^{13} \mathrm{C}_{\mathrm{POC}}$ increased with increasing algal POC (Fig. 5B). When algal POC concentration exceeded $50 \mu \mathrm{mol} \mathrm{L}-1$ (i.e., in the phase of growth limitation), $\delta^{13} \mathrm{C}_{\mathrm{POC}}$ decreased with increasing algal POC in both $\left[\mathrm{CO}_{2, \mathrm{aq}}\right]$ treatments (Fig. $5 B)$.

Isotope fractionation decreased with increasing algal POC (Fig. 5C) below $25 \mu \mathrm{mol}$ POC $\mathrm{L}^{-1}$ and increased with increasing POC above this level (Fig. 5C). As long as $\varepsilon_{p}$ decreased, the momentary fractionation $\left(\varepsilon_{p, \text { mom }}\right.$, which is based on the $\delta^{13} \mathrm{C}_{\mathrm{POC}}$ signal incorporated during the preceding cell division cycle) was lower than the accumulated fractionation $\left(\varepsilon_{p, \text { acc }}\right)$ (Fig. 5C). When $\varepsilon_{p}$ increased, $\varepsilon_{p \text {,mom }}$ was higher than $\varepsilon_{p \text {,acc }}$ (high $\left[\mathrm{CO}_{2, \text { aq }}\right]$ ) or approximately equal to $\varepsilon_{p \text {,acc }}$ (low $\left[\mathrm{CO}_{2, \mathrm{aq}}\right]$ ) (Fig. $5 \mathrm{C}$ ). Throughout the experiments, $\varepsilon_{p, \mathrm{mom}}$ was higher by $2-3 \%$ in the high compared to the low $\left[\mathrm{CO}_{2, \mathrm{aq}}\right]$ treatment (Fig. $5 \mathrm{C}$ ). The amplitude of changes in $\varepsilon_{p \text {,mom }}$ during the course of the experiments amounted to $2 \%$ (low $\left[\mathrm{CO}_{2, \mathrm{aq}}\right]$ ) and $3 \%$ (high $\left[\mathrm{CO}_{2, \mathrm{aq}}\right]$ ) (Fig. $5 \mathrm{C}$ ). This is in the same range as the offset in isotope fractionation between high $\left[\mathrm{CO}_{2, \mathrm{aq}}\right]$ (ca. $10-20 \mu \mathrm{mol} \mathrm{L}{ }^{-1}$ ) and low $\left[\mathrm{CO}_{2, \text { aq }}\right]$ (ca. 2$\left.4 \mu \mathrm{mol} \mathrm{L}{ }^{-1}\right)$ treatments.

Plotting $\varepsilon_{p \text {,mom }}$ against $\left[\mathrm{CO}_{2, \mathrm{aq}}\right]$, growth rate, and the quotient of carbon-specific growth rate $\left(\mu_{c}=\mu \cdot \mathrm{C}\right.$ cell quota) and $\left[\mathrm{CO}_{2, \text { aq }}\right]$ resulted in inverse linear relationships (Fig. $6 \mathrm{~A}, \mathrm{~B}, \mathrm{C})$.

\section{Discussion}

The present batch culture study was successful in producing artificial blooms of Skeletonema costatum that were comparable to natural blooms. The maximum algal cell concentration during our experiments was in the same range as observed during coastal S. costatum blooms (Sakshaug et al. 1983; Karentz and Smayda 1984). $\left[\mathrm{CO}_{2, \mathrm{aq}}\right]$ in our high $\left[\mathrm{CO}_{2, \mathrm{aq}}\right]$ treatment and $\delta^{13} \mathrm{C}_{\mathrm{CO}_{2}}$ in both high and low $\left[\mathrm{CO}_{2, \mathrm{aq}}\right]$ treatments showed changes comparable to those recorded during a $S$. costatum bloom in a Norwegian fjord (Kukert and Riebesell 1998). Isotope fractionation was between 10 and $13 \%$ in our high $\left[\mathrm{CO}_{2, \mathrm{aq}}\right]$ treatment, as well as in the natural $S$. costatum bloom studied by Kukert and Riebesell (1998). 


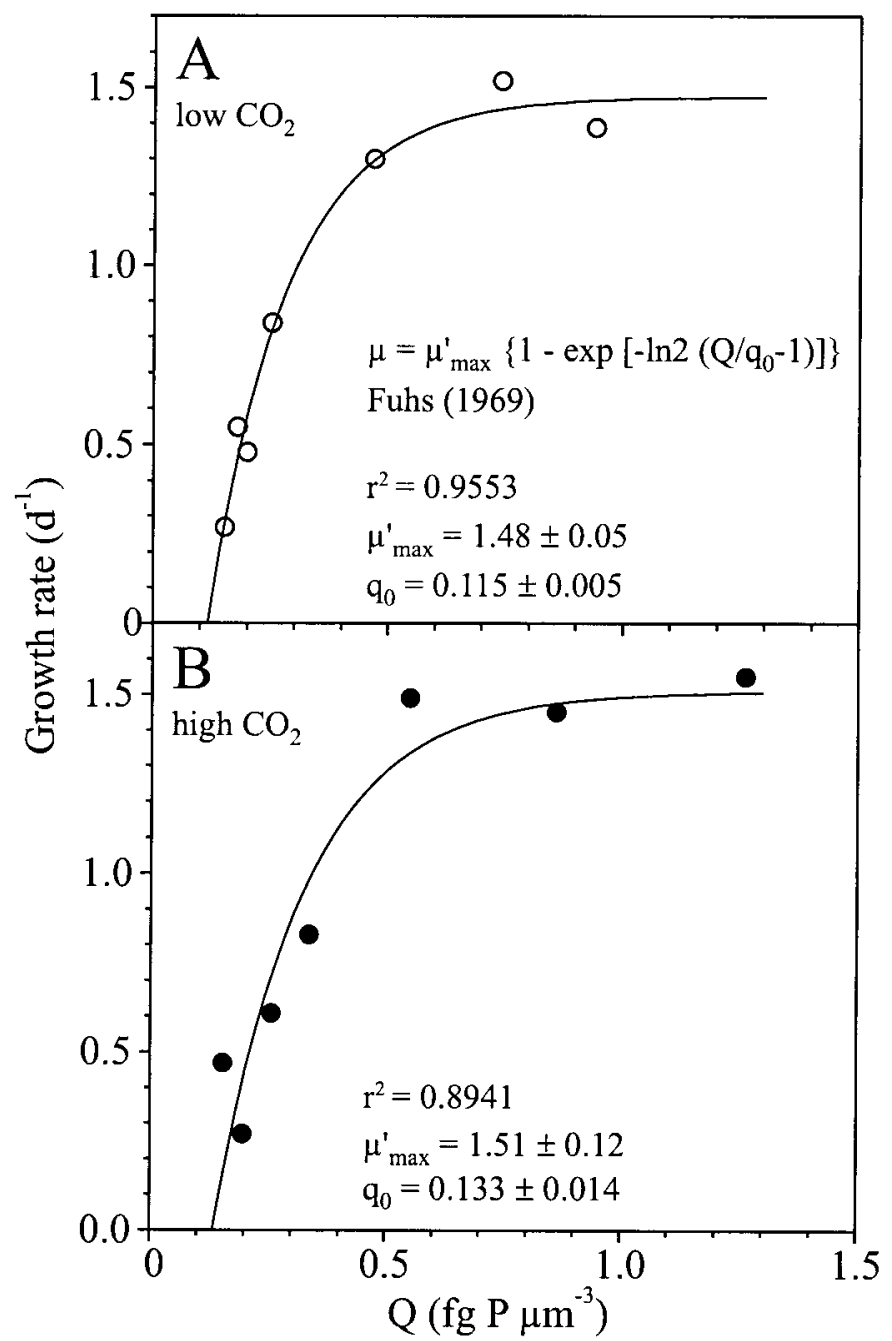

Fig. 7. S. costatum. Growth rate (calculated on the basis of the algal POC concentration of two consecutive samplings) versus cellular P quota $(\mathrm{Q}$, calculated as the mean of two consecutive samplings) in the experiments with low (A) and high (B) $\left[\mathrm{CO}_{2, \mathrm{aq}}\right]$. The fitted curve and the model parameters were calculated according to the Fuhs-model stated in (A).

Growth-The exponential growth rate of S. costatum was $7 \%$ lower in the low compared to the high $\left[\mathrm{CO}_{2, \mathrm{aq}}\right]$ treatment. This is in accordance with other studies on the same species (Burkhardt and Riebesell 1997; Burkhardt et al. 1999b). The observed slight difference in growth rate might be explained by the increasing energetic cost of the mechanisms necessary to satisfy cellular carbon demand under low $\left[\mathrm{CO}_{2, \mathrm{aq}}\right]$ (WolfGladrow et al. 1999).

Could the decrease in $\left[\mathrm{CO}_{2, \mathrm{aq}}\right]$ (Fig. 2C) rather than the decrease in cellular phosphorus quota (Fig. 3B) have been responsible for the observed strong decrease in growth rate (Fig. 7) during the course of each of our experiments? For the high $\left[\mathrm{CO}_{2, \mathrm{aq}}\right]$ experiment, this is out of the question because the reduction in $\left[\mathrm{CO}_{2, \mathrm{aq}}\right]$ (Fig. $2 \mathrm{C}$ ) was too small to have an effect on growth rate (cf. Burkhardt and Riebesell 1997; Burkhardt et al. 1999b). Even for the low $\left[\mathrm{CO}_{2, \mathrm{aq}}\right]$ experiment it is very likely that the declining $\mathrm{P}$ supply lim- ited the growth rate because only at $\left[\mathrm{CO}_{2, \mathrm{aq}}\right]$ as low as 1.5 $\mu \mathrm{mol} \mathrm{L} \mathrm{L}^{-1}$ (not reached in our experiment) Burkhardt and Riebesell (1997) found a $24 \%$ reduction in growth rate of $S$. costatum. Moreover, the analysis of the dependency of the growth rate on the cellular phosphorus quota by the model of Fuhs (1969) revealed no significant differences in the model parameters for both $\left[\mathrm{CO}_{2, \mathrm{aq}}\right]$ treatments (Fig. 7).

Cell quotas-The internal $\mathrm{P}$ pool of phytoplankton is known to respond to a restricted $\mathrm{P}$ supply according to the following scheme (Fuhs 1969; Riegman and Mur 1984). At first, the internal storage phosphorus is reduced with no effect on growth rate. Then, functional components such as phosphorylated intermediates and nucleotides, $\mathrm{P}$ of chloroplast lipids and RNA-P are reduced with increasing effect on growth rate. Finally, growth ceases and the cellular $\mathrm{P}$ becomes restricted to structural components such as $\mathrm{P}$ in membrane lipids and DNA. Since in our experiments $S$. costatum largely followed this scheme at least with respect to growth rate, this allows quantification of the various cellular $\mathrm{P}$ components.

According to the model proposed by Fuhs (1969) the mean structural P content (subsistence quota, $q_{0}$ ) of $S$. costatum was $0.115 \pm 0.005$ (low $\left[\mathrm{CO}_{2 \text {,aq }}\right]$ ) and $0.133 \pm 0.014$ fg $\mathrm{P} \mu \mathrm{m}^{-3}$ (high $\left[\mathrm{CO}_{2, \mathrm{aq}}\right]$ ) (Fig. 7). These values are not significantly different. Therefore a mean value $\left(q_{0}=0.12 \mathrm{fg} \mathrm{P}\right.$ $\left.\mu \mathrm{m}^{-3}\right)$ is used in the following calculations.

The critical phosphorus quota $\left(q_{c}\right)$ at which $95 \%$ of the maximum growth rate was reached (calculated from $q_{0}$ according to Wernicke and Nicklisch 1986) was $0.64 \mathrm{fg} \mathrm{P}$ $\mu \mathrm{m}^{-3}$. The functional $\mathrm{P}$ pool $\left(q_{c}-q_{0}\right)$ was $0.52 \mathrm{fg} \mathrm{P} \mu \mathrm{m}^{-3}$.

The maximum $\mathrm{P}$ cell quota observed $\left(q_{m}\right)$ was 1.0 (low $\left[\mathrm{CO}_{2, \mathrm{aq}}\right]$ ) and $1.5 \mathrm{fg} \mathrm{P} \mu \mathrm{m}^{-3}$ (high $\left[\mathrm{CO}_{2, \mathrm{aq}}\right]$ ). Because $q_{m}$ was not measured under steady state conditions, these values cannot be used to calculate the storage pool $\left(q_{m}-q_{c}\right)$. Under nonlimited conditions Harrison et al. (1977) reported a cell

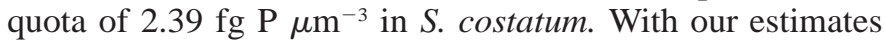
of $q_{c}$, this resulted in a maximum storage pool of $1.75 \mathrm{fg} \mathrm{P}$ $\mu \mathrm{m}^{-3}$.

Nutrient ratios-Obviously, the cellular $\mathrm{P}$ content of $S$. costatum was highly dynamic as external $\mathrm{P}$ concentration decreased during the course of the bloom. The resulting changes in $\mathrm{C}: \mathrm{P}$ ratios were much greater $(70$ to 1,000$)$ than changes observed in this species due to changes in $\left[\mathrm{CO}_{2, \mathrm{aq}}\right]$ under nutrient-replete conditions (35 to 80; Burkhardt and Riebesell 1997). This might explain why no effect of $\left[\mathrm{CO}_{2, \mathrm{aq}}\right]$ on $\mathrm{C}: \mathrm{P}$ ratios could be observed under low $\mathrm{P}$ concentrations in the present study. The finding that the $\mathrm{C}: \mathrm{N}$ ratio of $S$. costatum was $1.3 \mathrm{~mol} \mathrm{~mol}^{-1}$ higher under lower $\left[\mathrm{CO}_{2, \mathrm{aq}}\right]$, at least during exponential growth and the early P-limitation phase, corresponds to results by Burkhardt and Riebesell (1997) under nutrient-replete conditions. This difference was rather small and was no longer observed when $\mathrm{P}$ limitation continued. We therefore conclude that $\mathrm{CO}_{2}$-related variation in phytoplankton stoichiometry appears to play a minor role in the ocean carbon cycle under nutrient-limiting conditions. The same conclusion for nutrient-replete conditions was drawn by Burkhardt et al. (1999b), who found large changes in $\mathrm{C}: \mathrm{N}: \mathrm{P}$ ratios under ample nutrient supply only at $\left[\mathrm{CO}_{2, \mathrm{aq}}\right]$ 
levels much below those typically observed in ocean surface waters.

Carbon isotope fractionation-Monitoring carbon isotope fractionation during the course of the simulated blooms of Skeletonema costatum yielded four distinct results:

(1) In the high $\left[\mathrm{CO}_{2, \text { aq }}\right]$ treatment, calculation of the accumulated isotope fractionation $\left(\varepsilon_{p, \text { acc }}\right)$ underestimated the amplitude of changes in the momentary fractionation $\left(\varepsilon_{p, \text { mom }}\right)$ by about $1 \%$ (Fig. 5C). Although the need to account for this difference was previously recognized and applied for dense batch culture incubations (Erez et al. 1998), the present study suggests that this may also be of significancealbeit to a much smaller extent-under conditions where maximum algal biomass remains at a level representative for natural phytoplankton blooms.

(2) Isotope fractionation was consistently lower by $2-3 \%$ o in the low relative to the high $\left[\mathrm{CO}_{2, \mathrm{aq}}\right]$ treatment (Figs $5 \mathrm{C}$, 6B). This is in accordance with previous studies (e.g., Korb et al. 1998; Burkhardt et al. 1999a). Algae can adapt to low $\left[\mathrm{CO}_{2, \mathrm{aq}}\right]$ by an increase of the relative contribution of $\mathrm{HCO}_{3}^{-}$uptake to total carbon uptake or by reduced $\mathrm{CO}_{2}$ efflux (Goericke et al. 1994; Burkhardt et al. 1999a). Each of these adaptations leads to a decrease in isotope fractionation and can therefore explain the observed difference in isotope fractionation between both $\left[\mathrm{CO}_{2, \mathrm{aq}}\right]$ treatments. $\varepsilon_{p \text {,mom }}$ responses to changes in growth rate are very similar for both $\left[\mathrm{CO}_{2, \mathrm{aq}}\right]$ treatments, as indicated by nearly identical slopes for both high and low $\left[\mathrm{CO}_{2, \mathrm{aq}}\right]$-adapted cells, with a constant offset of ca. 2.5\%o (Fig. 6B).

(3) After a slight decrease in isotope fractionation during the time of exponential growth, $\varepsilon_{p}$ steadily increased during the rest of the bloom in both $\left[\mathrm{CO}_{2, \mathrm{aq}}\right]$ treatments (Fig. 5C). Although the former may reflect adaptation to the declining $\left[\mathrm{CO}_{2, \mathrm{aq}}\right]$ during the early phase of the bloom, the subsequent increase in $\varepsilon_{p}$-despite a further decline in $\left[\mathrm{CO}_{2, \mathrm{aq}}\right]$-is likely to have resulted from a continuous decrease in algal growth rate in response to increasing phosphorus limitation. Obviously, the effect of reduced carbon demand-due to decreasing growth rate-on isotope fractionation strongly dominated over that of declining $\mathrm{CO}_{2}$ availability. This also explains the inverse, (i.e., noncausative), linear relationship between $\varepsilon_{p \text {,mom }}$ and $\left[\mathrm{CO}_{2, \mathrm{aq}}\right]$ observed during each experiment (Fig. $6 \mathrm{~A})$. The same pattern, i.e., higher $\varepsilon_{p}$ values than expected for the corresponding $\left[\mathrm{CO}_{2, \mathrm{aq}}\right]$, was observed during the final stage of a natural N-limited bloom of S. costatum by Kukert and Riebesell (1998).

(4) The two $\left[\mathrm{CO}_{2, \mathrm{aq}}\right]$ treatments yielded different relationships when $\varepsilon_{p}$ was plotted versus $\mu_{c} /\left[\mathrm{CO}_{2, \mathrm{aq}}\right]$ (Fig. 6c). The slopes of both regression lines were mainly controlled by $\mu_{c}$ as shown by the fact that they changed by only $5 \%$ when $\left[\mathrm{CO}_{2, \mathrm{aq}}\right]$ was assumed to be constant throughout each $\left[\mathrm{CO}_{2, \mathrm{aq}}\right]$ treatment (not shown). Although low and high $\left[\mathrm{CO}_{2, \mathrm{aq}}\right]$ yielded almost identical maximum growth rates (Fig. 1), a distinct difference was obtained in isotope fractionation (Fig. 6B). This implies that carbon fluxes in and out of the cell differed between $\left[\mathrm{CO}_{2, \mathrm{aq}}\right]$ treatments, possibly indicating a difference in inorganic carbon acquisition. These results question the existence of a unique relationship between $\varepsilon_{p}$ and $\mu_{c} /\left[\mathrm{CO}_{2, \mathrm{aq}}\right]$ that could be used to estimate phytoplankton growth rates from measurements of $\varepsilon_{p}$ and $\left[\mathrm{CO}_{2, \mathrm{aq}}\right]$ (Laws et al. 1997).

If applicable to the natural environment, our results are relevant for the interpretation of carbon isotope composition both in suspended particulate and sedimentary organic matter. Obviously, half of the biomass accumulating during the course of a phytoplankton bloom is produced during the last cell doubling, i.e., during a period when algal growth rates become limited due to nutrient depletion and $\mathrm{CO}_{2}$ concentration has decreased due to photosynthetic carbon fixation. Thus, the isotope signal present at the end of a bloom closely reflects the conditions prevailing during the final stage of the bloom. As indicated by the results of this study, this signal can differ significantly from that produced during the phase of exponential growth. The magnitude of this difference depends on a number of factors, including the amount of biomass accumulated during the bloom as well as the duration and extent of nutrient-limited growth.

For the interpretation of carbon isotope measurements obtained in areas and at times of phytoplankton bloom development, it may therefore become critical to consider the developmental stage of the bloom. The time of sampling, i.e., whether during the phase of nutrient-replete, exponential growth or at times of nutrient-limited growth, can significantly affect the isotopic signal in suspended organic matter (or components isolated from it) and affects the relationship of $\varepsilon_{p}$ with growth rate and $\left[\mathrm{CO}_{2, \text { aq }}\right]$ obtained from it. Moreover, since $\varepsilon_{p}$ responses may significantly differ also depending on the growth-limiting resource (Riebesell et al. 2000), it could be of similar importance under these conditions to determine which is the factor limiting phytoplankton growth. The magnitude of these effects may be sufficient to mask the possible $\mathrm{CO}_{2}$-related effect on isotope fractionation.

Phytoplankton bloom development is intimately linked to the nutrient and mixing (i.e., light) regimes within the oceanic surface layer. Large-scale geographical differences in the physical forcing controlling surface ocean nutrient and mixing regimes have led Longhurst (1998) to partition the ocean into biogeochemical provinces, areas that share a common physical forcing. The environmental conditions controlling phytoplankton growth dynamics strongly differ between these provinces, supporting a wide range of pelagic ecosystems from high-biomass new production systems to low-biomass recycling systems. Thus, the potential significance of bloom-related effects on isotope fractionation is expected to differ greatly between provinces. This should be considered when comparing carbon isotope data of sedimentary organic matter obtained at sites located in different biogeochemical provinces. Also, since the boundaries between biogeochemical provinces are expected to have shifted over geological time, changes in carbon isotope signatures in down-core records at any given location may partly reflect long-term shifts in the overall mixing and nutrient regime at that location. These considerations may severely complicate the interpretation of carbon isotope measurements in sedimentary organic matter. 


\section{References}

Berdalet, E., M. Latasa, AND M. Estrada. 1994. Effect of nitrogen or phosphorus starvation on nucleic acid and protein content of Heterocapsa sp. J. Plankton Res. 16: 303-316.

Brewer, P. G., A. L. Bradshaw, and R. T. Williams. 1986. Measurement of total carbon dioxide and alkalinity in the North Atlantic ocean in 1981, p. 358-381. In J. R. Trabalka and D. E. Reichle [eds.], The changing carbon cycle-a global analysis. Springer.

BurkHARDT, S., AND U. RiebeSELL. 1997. $\mathrm{CO}_{2}$ availability affects elemental composition $(\mathrm{C}: \mathrm{N}: \mathrm{P})$ of the marine diatom Skeletonema costatum. Mar. Ecol. Prog. Ser. 155: 67-76.

$\longrightarrow,-$ AND I. ZONDERVAN. 1999a. Effects of growth rate, $\mathrm{CO}_{2}$ concentration, and cell size on the stable carbon isotope fractionation in marine phytoplankton. Geochim. Cosmochim. Acta 63: 3729-3741.

- I. ZONDERVAN, AND U. RIEBESELL. 1999b. Effect of $\mathrm{CO}_{2}$ concentration on $\mathrm{C}: \mathrm{N}: \mathrm{P}$ ratio in marine phytoplankton: A species comparison. Limnol. Oceanogr. 44: 683-690.

Erez, J., A. Bouevitch, and A. Kaplan. 1998. Carbon isotope fractionation by photosynthetic aquatic microorganisms: Experiments with Synechococcus PCC7942, and a simple carbon flux model. Can. J. Bot. 76: 1109-1118.

Freeman, K. H., AND J. M. HAYES. 1992. Fractionation of carbon isotopes by phytoplankton and estimates of ancient $\mathrm{CO}_{2}$ levels. Glob. Biogeochem. Cycles 6: 185-198.

FrY, B. $1996 .{ }^{13} \mathrm{C} /{ }^{12} \mathrm{C}$ fractionation by marine diatoms. Mar. Ecol. Prog. Ser. 134: 283-294.

Funs, G. W. 1969. Phosphorus content and rate of growth in the diatoms Cyclotella nana and Thalassiosira fluviatilis. J. Phycol. 5: 312-321.

Gilstad, M., G. Johnsen, And E. Sakshaug. 1993. Photosynthetic parameters, pigment composition and respiration rates of the marine diatom Skeletonema costatum grown in continuous light and a 12:12 h light-dark cycle. J. Plankton Res. 15: 939951.

Goericke, R., J. P. Montoya, And B. Fry. 1994. Physiology of isotopic fractionation in algae and cyanobacteria, p. 187-221. In K. Lajtha and R. H. Michener [eds.], Stable isotopes in ecology and environmental science. Blackwell.

Goyet, C., AND A. Poisson. 1989. New determination of carbonic acid dissociation constants in seawater as a function of temperature and salinity. Deep-Sea Res. A 36: 1635-1654.

GRAN, G. 1952. Determination of the equivalence point in potentiometric titrations of seawater with hydrochloric acid. Oceanol. Acta 5: 209-218.

Guillard, R. R. L., AND J. H. Ryther. 1962. Studies of marine planktonic diatoms. Can. J. Microbiol. 8: 229-239.

Harrison, P. J., H. L. Conway, R. W. Holmes, and C. O. Davis. 1977. Marine diatoms grown in chemostats under silicate or ammonium limitation. III. Cellular chemical composition and morphology of Chaetoceros debilis, Skeletonema costatum, and Thalassiosira gravida. Mar. Biol. 43: 19-31.

Johnson, K. M., K. D. Wills, D. B. ButleR, W. K. Johnson, AND C. S. Wong. 1993. Coulometric total carbon dioxide analysis for marine studies: Maximizing the performance of an automated gas extraction system and coulometric detector. Mar. Chem. 44: 167-187.

Johnston, A. M., And H. Kennedy. 1998. Carbon stable isotope fractionation in marine systems: Open ocean studies and laboratory studies, p. 239-256. In H. Griffiths [ed.], Stable isotopes-integration of biological, ecological and geochemical processes. BIOS.
KAREnTZ, D., AND T. J. SMAYdA. 1984. Temperature and seasonal occurrence patterns of 30 dominant phytoplankton species in Narragansett Bay over a 22-year period (1959-1980). Mar. Ecol. Prog. Ser. 18: 277-293.

Korb, R. E., J. A. RAven, And A. M. Johnston. 1998. Relationship between aqueous $\mathrm{CO}_{2}$ concentrations and stable carbon isotope discrimination in the diatoms Chaetoceros calcitrans and Ditylum brightwellii. Mar. Ecol. Prog. Ser. 171: 303-305.

KuKert, H., AND U. Riebesell. 1998. Phytoplankton carbon isotope fractionation during a diatom spring bloom in a Norwegian fjord. Mar. Ecol. Prog. Ser. 173: 127-137.

Laws, E. A., R. R. Bidigare, and B. N. Popp. 1997. Effect of growth rate and $\mathrm{CO}_{2}$ concentration on carbon isotopic fractionation by the marine diatom Phaeodactylum tricornutum. Limnol. Oceanogr. 42: 1552-1560.

LONGHURST, A. R. 1998. Ecological geography of the sea. Academic.

Mook, W. G., J. C. Bommerson, and W. H. Staverman. 1974. Carbon isotope fractionation between dissolved bicarbonate and gaseous carbon dioxide. Earth Planet. Sci. Lett. 22: 169176.

Popp, B. N., E. A. Laws, R. R. Bidigare, J. E. Dore, K. L. HanSON, AND S. G. WAKEHAM. 1998. Effect of phytoplankton cell geometry on carbon isotopic fractionation. Geochim. Cosmochim. Acta 62: 69-77.

RaU, G. H., U. Riebesell, ANd D. Wolf-Gladrow. 1996. A model of photosynthetic ${ }^{13} \mathrm{C}$ fractionation by marine phytoplankton based on diffusive molecular $\mathrm{CO}_{2}$ uptake. Mar. Ecol. Prog. Ser. 133: $275-285$.

RHEE, G.-Y. 1978. Effects of N:P atomic ratios and nitrate limitation on algal growth, cell composition, and nitrate uptake. Limnol. Oceanogr. 23: 10-25.

Riebesell, U., S. Burkhardt, A. Dauelsberg, and B. Kroon. 2000. Carbon isotope fractionation by a marine diatom: Dependence on the growth-rate limiting resource. Mar. Ecol. Prog. Ser. 193: 295-303.

Riegman, R., AND L. R. MUR. 1984. Theoretical considerations on growth kinetics and physiological adaptation of nutrient-limited phytoplankton. Arch. Microbiol. 140: 96-100.

Sakshaug, E., K. Andresen, S. Myklestad, and Y. Olsen. 1983. Nutrient status of phytoplankton communities in Norwegian waters (marine, brackish, and fresh) as revealed by their chemical composition. J. Plankton Res. 5: 175-196.

, AND O. Holm-HANSEN. 1977. Chemical composition of Skeletonema costatum (Grev.) Cleve and Pavlova (Monochrysis) lutheri (Droop) Green as a function of nitrate-, phosphate-, and iron-limited growth. J. Exp. Mar. Biol. Ecol. 29: 1-34.

StRICKLAND, J. D. H., AND T. R. PARSONS. 1972. A practical handbook of seawater analysis. Bull. Fish. Res. Board Can. 167.

VÅRUM, K. M., AND S. MYKLESTAD. 1984. Effects of light, salinity and nutrient limitation on the production of $\beta$-1,3-D-glucan and exo-D-glucanase activity in Skeletonema costatum. J. Exp. Mar. Biol. Ecol. 83: 13-25.

Wernicke, P., AND A. NicKLISCH. 1986. Light/dark cycle and temperature-their impact on phosphate-limited growth of Oscillatoria redekei van Goor in semicontinuous culture. Int. Rev. Gesamten Hydrobiol. 71: 297-313.

Wolf-Gladrow, D. A., U. Riebesell, S. Burkhardt, and J. BiJMA. 1999. Direct effects of $\mathrm{CO}_{2}$ concentration on growth and isotopic composition of marine plankton. Tellus 51B: 461-476.

Received: 6 June 2000 Amended: 27 October 2000 Accepted: 17 November 2000 